\title{
MERGAIČIŲ IR BERNIUKŲ ŠOKLUMO KAITA
}

\author{
Eduardas Rudas, Albertas Skurvydas, Dalia Mickevičienė, Daiva Bulotienė \\ Lietuvos kūno kultūros akademija, Kaunas, Lietuva
}

Eduardas Rudas. Biologijos krypties doktorantas. Lietuvos kūno kultūros akademijos Dvikovos sporto šakų katedros asistentas. Mokslinių tyrimų kryptis — jaunesniojo mokyklinio amžiaus vaikų šoklumo judesių kaita.

\section{SANTRAUKA}

Straipsnyje lyginama jaunesniojo mokyklinio amžiaus ketvirtu klasiu (10 \pm 0,7 metu) berniuku ir mergaičiı šoklumo kaita, šiq savybę ugdant du ménesius. Buvo tiriami 33 ketvirtos klasès moksleiviai: 16 berniuku ir 17 mergaičiu. Tyrimo tikslas — nustatyti ir palyginti jaunesniojo mokyklinio amžiaus berniuku ir mergaičiu šoklumo kaita per du mènesius.

Šoklumas ugdytas du mènesius du kartus per savaitę. Treniruotès metu po neintensyvios 10 minučiu pramankštos tiriamieji kas 30 sekundžiu atliko po 50 vertikaliu šuoliu. Rekomenduojama šuolį atlikti kiek galima aukščiau. Šuolio aukščiui nustatyti buvo naudojama kontaktine plokštè, sujungta su elektroniniu šuolio aukščio ir atsispyrimo laiko matuokliu. Moksleiviu šuoliu aukščio rezultatai buvo užrašomi asmeniniame protokole. Tyrimo rezultatai apdoroti matematinès statistikos metodais.

Du mėnesius ugdydami jaunesniojo mokyklinio amžiaus vaiku šoklumq nustatėme, kad berniuku ir mergaičiı šoklumas dèl treniruočiu reikšmingai pagerëjo, lyginant su pirma treniruote, ir berniuku vertikalaus šuolio rezultatai reikšmingai skyrèsi nuo mergaičiu. Rezultatu prieaugio skirtumas statistiškai patikimas. Paaiškejjo, kad berniuku ir mergaičiu šuoliu rezultatai gerëjo tolygiai. Dèl treniruočiı padidejo moksleiviu šoklumo rezultatu vidurkio sklaida. Berniukai labiau pagerino savo šuoliu vidurkio rezultatus nei mergaités. Tyrimas parodè, kad iš pirmos treniruotès vertikaliu šuoliu rodikliu vidurkio negalima prognozuoti galutiniu rezultatu.

Raktažodžiai: berniuku ir mergaičiı šoklumas, raumenu nuovargis, šoklumo ugdymas.

\section{IVADAS}

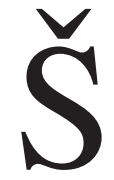
oklumas priklauso nuo daugelio specifiniu griaučiu raumenu funkcinių savybių, kompozicijos, t. y. nuo greitųjų ir lètujjų raumeninių skaidulų procentinès sudèties, nuo elastinių ir mioelektrinių raumens savybių panaudojimo amortizacinių pratimų metu. Šoklumas ir greitumas - vyraujantys kompleksiniai motoriniai i̇vairių šakų sportininkų gebejjimai (Bosco et al., 1983; Balsom et al., 1992). Sporto praktikoje taikoma nemažai pratimų, biodinamine struktūra panašių i šuolius, kuriuos atliekant realizuojama raumenu staigioji jèga. Dažnai sportininkas, kurio staigiosios jègos rodikliai nèra geri, yra labai šoklus (Skurvydas ir kt., 1988). Raumenu susitraukimo efektyvumas priklauso nuo daugelio fiziologinių, biocheminių veiksnių, kuriuos lemia ne tik motorinès sistemos augimas ir brendimas (Malina, Bouchard, 1991), bet ir treniruočių krūviai (Häkkinen, 1994; Mamkus, 1998; Stanislovaitis, 1998). Šoklumas gerèja organizmui 
augant ir bręstant, todèl labai reikšmingas laikotarpis yra paauglystè (Malina, Bouchard, 1991; Spirduso,1995). Šiuo tarpsniu motorinis aktyvumas didejja, taip pat sparčiau lavejja motorika ir dèl natūralaus brendimo (Jaščaninas ir kt., 1989; Malina, Bouchard, 1991; Glenmark et al.,1992; Kraemer \& Fleck, 1993). Absoliutus paaugliu judejjimo reakcijos greitis ypač padidejja 8-12 gyvenimo metais (Karoblis, 1999). Literatūroje dažnai nurodoma, kad jaunas organizmas geba „plastiškai“ adaptuotis prie pratybų krūvių (Malina, Bouchard, 1991; Komi, 1992; Kraemer \& Fleck, 1993), tačiau neaišku, kokie krūviai, jų struktūra, apimtis ir intensyvumas turètų būti optimalūs, t. y. skatintų, o ne slopintų natūralaus augimo ir brendimo tempus. Tinkamiausias amžius greitumui ugdyti - 9-13 gyvenimo metai (Karoblis, 1999). Kai kurie autoriai teigia, kad ilgos trukmès krūviai gali lemti greitai susitraukiančių (greitujų) raumeninių skaidulų transformavimąsi į lètai susitraukiančias (lètąsias) raumenines skaidulas (Booth \& Thomason, 1991; Salmons, 1994). Ugdant šokluma, turètu gerèti greitumo ir raumenu galingumo rodikliai. Sporto pedagogai ir mokslininkai, remdamiesi organizmo adaptacijos dèsningumais, taiko keletą pagrindinių sporto treniruotès krūvio planavimo sistemų, kurios skiriasi krūvio paskirstymu ir jo atlikimo specifika (Komi, 1992; Wilmore \& Costill, 1994; Karoblis, 1999). Neaišku, kaip šoklumo krūviai, trunkantys du mėnesius, veikia jaunesniojo mokyklinio amžiaus moksleivių šoklumą.

Tyrimo tikslas - nustatyti ir palyginti jaunesniojo mokyklinio amžiaus (10 metu) berniuku ir mergaičiu šoklumo kaitą per du ménesius.

Hipotezès:

- Remdamiesi organizmo adaptacijos prie fiziniu krūvių biologiniais dėsningumais (Balsom et al., 1992; Glenmark et al., 1992; Komi, 1992) darytume prielaida, kad 8 savaičių krūviai didins šoklumo rodiklius.

- Manytume, kad berniukai, ugdydami šoklumą 2 mènesius, savo rezultatus pagerins labiau nei mergaitès, nes mergaičių raumenu jẻga siekia 75-90\% to paties amžiaus berniukų raumenu jègos (Malina, Bouchard, 1991).

\section{TYRIMO METODAI IR ORGANIZAVIMAS}

Šoklumo testavimas. Vienkartiniai vertikalūs šuoliai buvo fiksuojami naudojant LKKA
Žmogaus motorikos laboratorijoje aprobuotus metodus (Mamkus, 1998; Stanislovaitis, 1998; Zachovajevas, 1998). Šuoliui matuoti buvo naudojama kontaktinè plokštė $(60 \times 60 \mathrm{~cm})$, laidais sujungta su elektroniniu šuolio aukščio ir atsispyrimo laiko matuokliu. Šuolio aukštis buvo nustatomas pagal lèkimo fazès trukmę. Lèkimo trukmè perskaičiuojama i šuolio aukštį naudojant formulę (Bosco et al., 1983):

$$
h=\frac{g \times t_{p}^{2}}{8}=1,22625 \times t_{p}^{2},
$$

čia h — šuolio aukštis (m), g — laisvojo kritimo pagreitis $\left(9,80665 \mathrm{~m} / \mathrm{s}^{2}\right), \mathrm{t}_{\mathrm{p}}$ - lékimo trukmè (s).

Vertikalūs šuoliai atliekami amortizuojamai pritupiant iki $90^{\circ}$ (hp 90) kampo per kelius (kampas kontroliuojamas stebint), rankos — ant juosmens.

Matematinė statistika. Vertikalių šuolių rezultatai buvo apdoroti matematinès statistikos metodais apskaičiuojant:

- aritmetini vidurki;

- vidutini kvadratini nuokrypi;

- procentinę rezultatų kaitą;

- skirtumo tarp aritmetinių vidurkių reikšmingumą pagal dvipusi Stjudento $t$ kriterijų (aritmetinių vidurkių skirtumo reikšmingumo lygmuo buvo laikomas svarbiu, kai paklaida $(\mathrm{p}<0,05)$ mažesnè nei $5 \%$;

- ryšį tarp rodiklių (taikant Pirsono koreliacijos koeficienta).

Tiriamieji. Buvo tiriami Palemono vidurinès mokyklos normaliai išsivystę sveiki jaunesniojo mokyklinio amžiaus ketvirtų klasių moksleiviai: berniukai $(n=16)$, mergaitès $(n=17)$.

Tyrimo organizavimas. Moksleiviai ugdè šoklumą 8 savaites (du kartus per savaitę pirmoje dienos pusejje). Tiriamieji po 10 minučiu neintensyvios pramankštos (tempimo pratimų, lèto bėgimo (pulsas bėgimo pabaigoje iki 110-120 tv. / min), lengvų šuoliuku) ant kontaktinės plokštès atliko vertikalius šuolius, amortizuojamai pritūpdami per kelius iki $90^{\circ}$ kampo. Rankos — ant juosmens. Remiantis C. Bosco ir P. Komi (1979) metodika, buvo apskaičiuojamas vertikalaus šuolio aukštis (h). Visi tiriamieji kiekvieną treniruočių dieną atlikdavo po 50 vertikalių šuoliu (intervalai tarp šuoliu — 30 sekundžių). Rekomenduojama šuolį atlikti kiek i̇manoma aukščiau, stengiantis pagerinti asmeninį rezultatą. Vertikalių šuolių re- 
zultatai užrašomi į asmeninị kiekvieno moksleivio protokolą.

\section{REZULTATAI}

Buvo tiriami 33 sveiki normaliai fiziškai išsivystę moksleiviai: 16 berniukų ir 17 mergaičiu (lent.). Kaip matyti lentelejje, moksleivių amžius vienodas, standartinis nuokrypis nèra didelis. Beveik nesiskiria tiriamujų vaikų ūgis ir svoris.

Iš grafiko matyti (1 pav.), kad 8 savaites ugdant šoklumą (kas 30 sekundžių atliekant 50 šuoliu) šuolių aukščio vidurkiai nuosekliai didejjo. Tyrimo pradžioje berniukų ir mergaičiu šuoliu rezultatų vidurkis beveik nesiskyrè. Berniukų šuolių rezultatų vidurkis po 15 treniruočių pagerejja daugiau kaip $11 \mathrm{~cm}$, mergaičiu $-6,3 \mathrm{~cm}$. Tiek berniuku, tiek mergaičių vertikalių šuolių aukščio aritmetinio vidurkio analizè rodo, kad rodikliai pamažu gerèja. Berniukų rezultatai nereikšmingai skiriasi jau per antrą treniruotę, tuo tarpu mergaičių vertikalių šuolių rezultatų vidurkio skirtumas statistiškai patikimas $(\mathrm{p}<0,05)$ tik nuo septintos treniruotès, lyginant su pirma treniruote. Berniuku ir mergaičių šuolių rezultatai gerèja tolygiai, nors berniukų šuolių rezultatai reikšmingai skyrèsi nuo mergaičių.

Palyginus berniukų ir mergaičių vertikalių šuolių rezultatų vidurkio prieaugio tempus su pirmos treniruotès rezultatais (2 pav.) matyti, kad tiek berniuku, tiek mergaičių rezultatai nuosekliai gerejja. Vis tik berniukai jau antroje treniruotejje pagerino savo rezultatus, kurių prieaugio tempai vos ne dvigubai spartesni.

Pažvelgus i berniukų ir mergaičių šuolių rezultatų vidurkio procentinès raiškos kaitą (3 pav.) matyti, kad ji nuolatos dideja, lyginant su pirmos treniruotės rezultatais. Berniukų šuoliu rezultatų prieaugis po šoklumo ugdymo treniruočių sudaro net 53\%, mergaičiu - 29,7\%, lyginant su pirmos treniruotès rezultatais. Berniukų rezultatai patikimai gerèja jau trečioje treniruotejje, mergaičiu — nuo 7-os treniruotès $(*-p<0,05)$.

Pažvelgus i standartinio nuokrypio kreives
Lentelè. Ketvirtų klasių berniukų ir mergaičių amžiaus, ùgio ir svorio parametrai

Pastaba. ${ }^{*}-\mathrm{p}<0,05$.

1 pav. Šuolių rezultatų vidurkis

2 pav. Šuolių rezultatų vidurkio prieaugio tempai $(\mathrm{cm})$, lyginant su pirmos treniruotės rodikliais

\begin{tabular}{|l|c|c|c|}
\hline Pidurkis & Amžius, m. & Ūgis, cm & Svoris, kg \\
\hline Berniukų & $10 \pm 0,7$ & $143,0 \pm 6,5$ & $33,1 \pm 5,1$ \\
\hline Mergaičių & $10 \pm 0,5$ & $143,4 \pm 5,7$ & $33,4 \pm 5,1$ \\
\hline
\end{tabular}
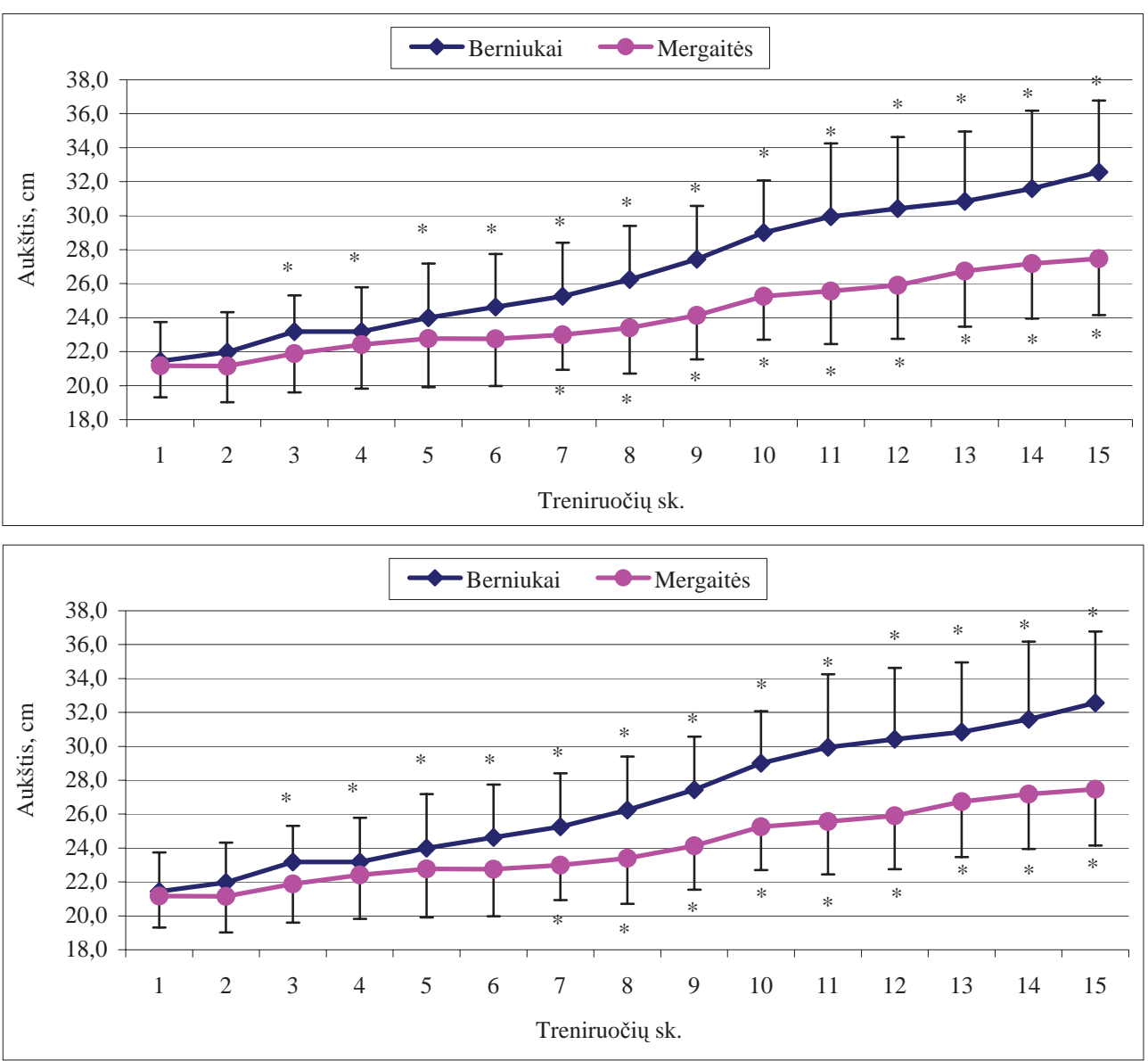


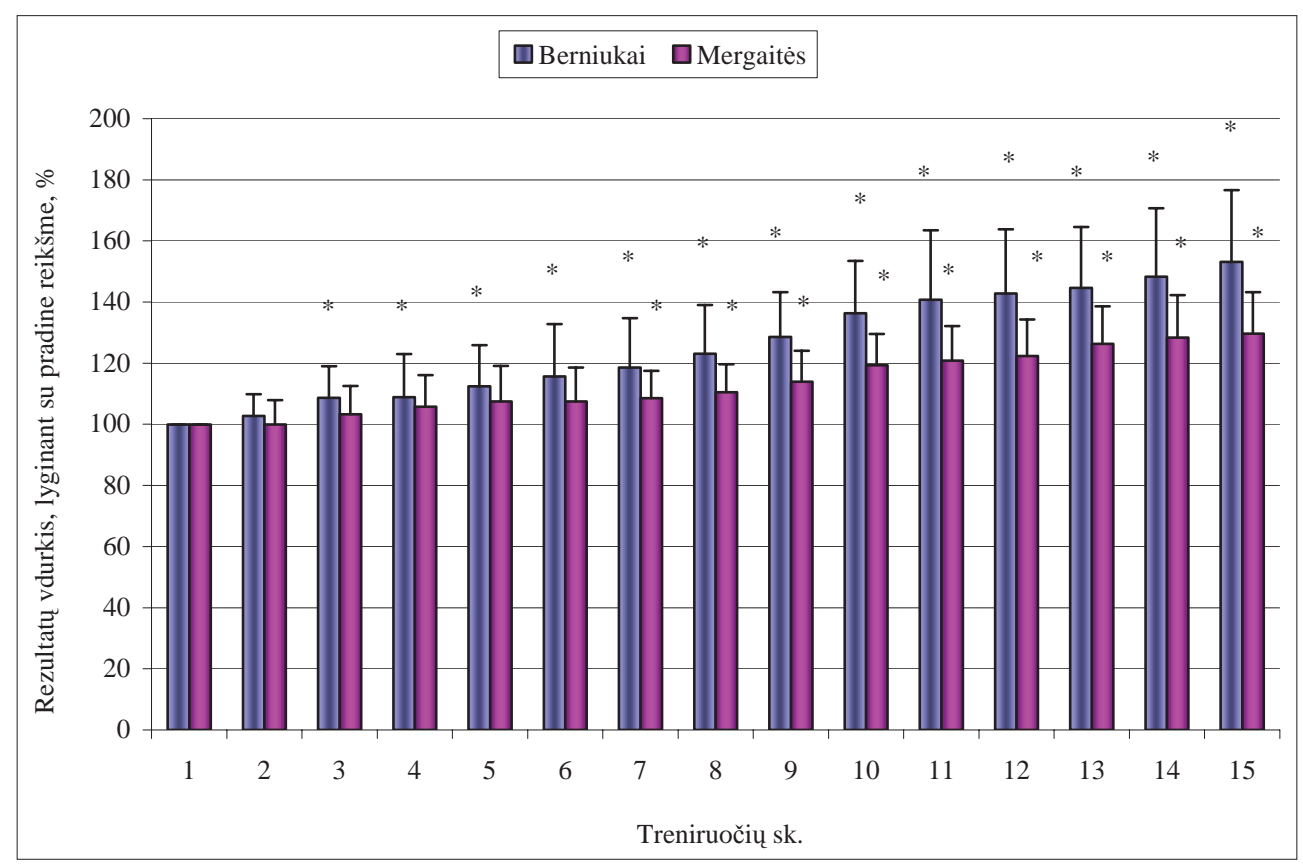

3 pav. Šuolių rezultatų vidurkio procentinè kaita

Pastaba. ${ }^{*}-\mathrm{p}<0,05$.
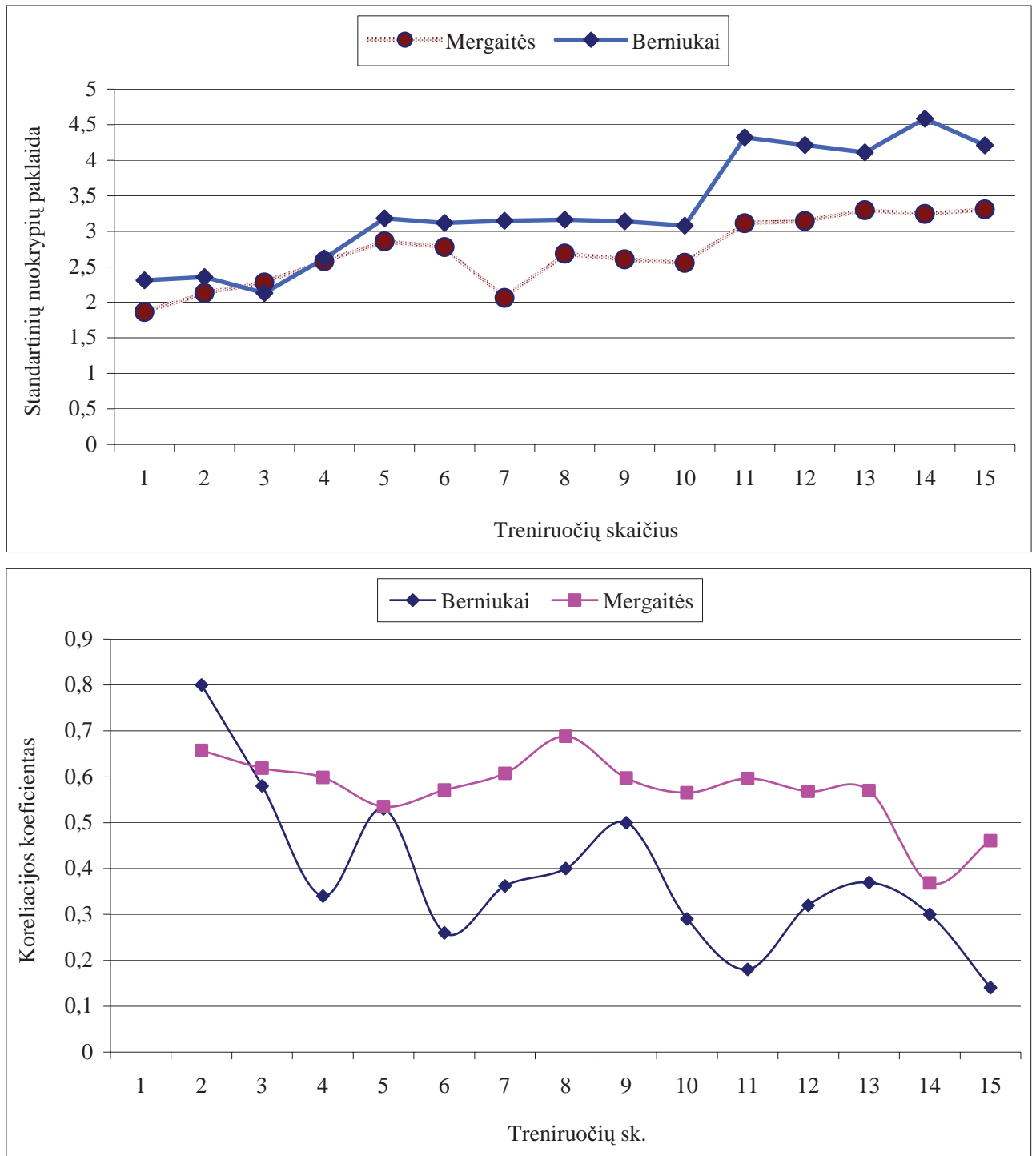

5 pav. Šuolių rezultatų koreliacijos koeficientų sklaida, lyginant su pirmos treniruotès rodikliais

(4 pav.) matyti, kad ir berniuku, ir mergaičių vidutinis kvadratinis nuokrypis nuo rezultatų vidurkio išaugo. Berniukų padidejjo iki 1,9 (nuo 2,3 iki 4,2), mergaičių - 1,4 (nuo 1,9 iki 3,3). Tai leidžia da- 
6 pav. Šuolių rezultatų aritmetinis vidurkis pagal Stjudento t kriteriju (TTEST)

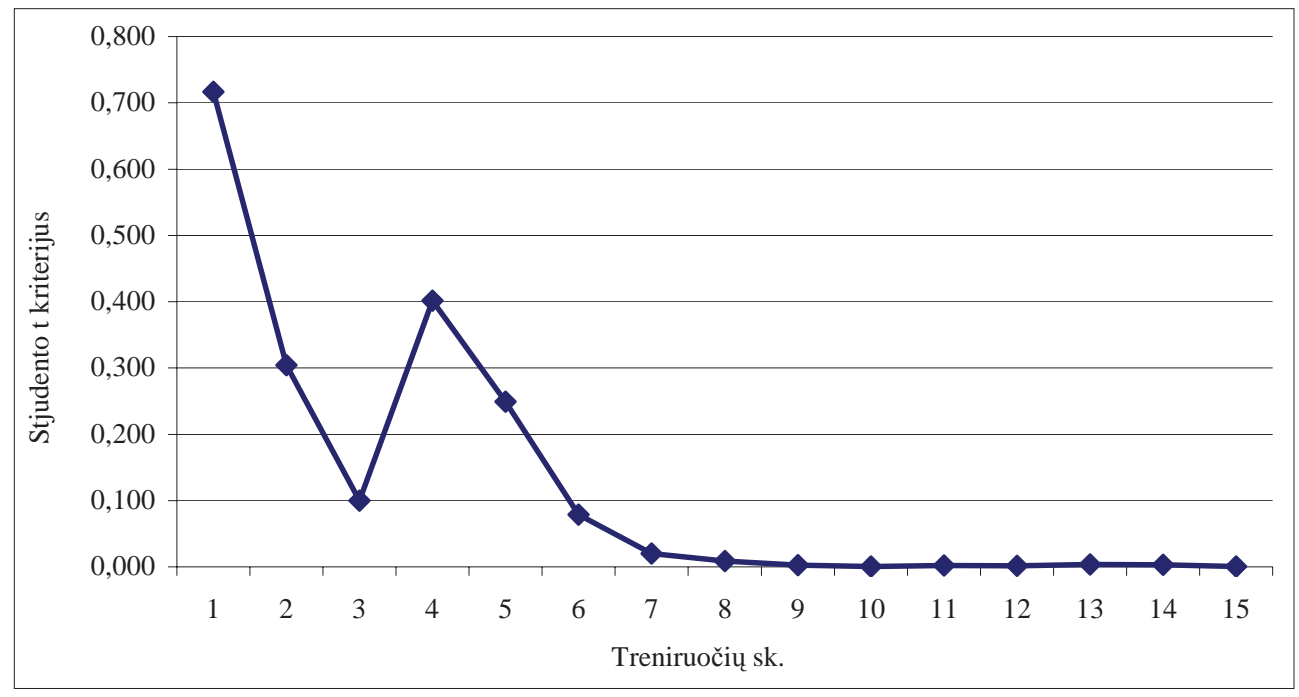

ryti išvadą, kad tiek berniuku, tiek mergaičiu šuolių rezultatų sklaida dėl treniruočių padidejjo. Visgi berniuku rezultatų sklaida didesnė nei mergaičių tiek treniruočiu pradžioje, tiek pabaigoje, taip pat analizuojant sklaidos padidejjimą dèl treniruočiu poveikio. Tai rodo didesnị atotrūkị nuo vidutinių rezultatu.

Moksleivių vertikalių šuolių rezultatų koreliacijos koeficientas, lyginant su pirmos treniruotès rodikliais, krinta (5 pav.). Ilgesni laiką pastebimas vidutinis koreliacinis ryšys tarp mergaičių rodiklių, paskutinėse treniruotėse nukrinta iki silpno. Per paskutinę treniruotę nustatytas labai silpnas koreliacinis ryšys tarp šių berniukų rezultatų. Galima teigti, kad pagal pirmos treniruotès šoklumo rodiklius negalima prognozuoti galutiniu rezultatu.

Stjudento kriterijus (6 pav.), esant statistiškai vienodoms dispersijoms, rodo, kad nuo pirmos iki šeštos treniruotès skirtumas tarp abieju grupių rezultatų yra statistiškai nepatikimas, jie yra statistiškai vienodi $(\mathrm{p}>0,05)$. Nuo septintos iki penkioliktos treniruotės berniuku ir mergaičiu rezultatai skiriasi patikimai $(\mathrm{p}<0,05)$.

\section{REZULTATŲ APTARIMAS}

Sporto pedagogai ir mokslininkai, tiriantys šoklumo ugdymo priemonių ir metodų efektyvumą (Malina, Bouchard, 1991; Kraemer \& Fleck, 1993; Häkkinen, 1994; Mamkus, 1998; Stanislovaitis, 1998; Kamandulis, Skurvydas, 2003), pastebi, kad ugdant šią savybę gerejja greitumo ir raumenu galingumo rodikliai. Atlikto tyrimo rezultatai parodè, kad tiek tyrimo pradžioje, tiek jo pabaigoje visu vaikų vertikalaus šuolio rezultatai yra skirtingi. Šuolio aukštị lemia daug veiksnių. Vertikalus šuo- lis yra vientisas judesys ir jo atlikimas, kaip teigia kai kurie mokslininkai, priklauso nuo vienos motorinès programos (Schmidth, 1988). Maždaug trečiais gyvenimo metais susiformuoja pagrindiniai šuolio atlikimo motorinès programos ypatumai, o tolesniais ontogenezès tarpsniais ji tik tobulèja. Visgi motorinè programa, kaip ir kiti refleksiniai bei raumeniniai mechanizmai, gali būti modifikuojami priklausomai nuo šuolio būdo, mokèjimo ji atlikti bei susikaupimo laipsnio (Schmidt, 1988; Komi, 1992). Šuolio amortizuojamai pritupiant (hp 90) aukštis priklauso nuo gebėjimo panaudoti elastinę raumenų energiją ir tempimo refleksą (Bosco et al., 1983). Toks gebejjimas priklauso nuo raumenu kompozicijos - greiti sportininkai geriau panaudoja elastinę energiją greitai ir lengvai amortizuojamai pritūpdami, o lèti — lètai ir smarkiai pritūpdami (Skurvydas ir kt., 1988; Komi, 1992). Taigi aiškinantis vaikų šoklumo skirtumus būtina atsižvelgti į registruojamo šoklumo rodiklio specifika, nes vienų šoklumas labiau priklauso nuo genetinių veiksnių kitų — nuo ugdymo pobūdžio. Nors mes netyreme raumenų kompozicijos, manome, kad šoklesni yra tie vaikai, kurių raumenyse vyrauja greitosios RS, arba iš prigimties stipresni. Tai patvirtina ir kiti autoriai (Jaščaninas ir kt., 1989; Häkkinen, 1994). Puberteto metu vaikų fizinis parengtumas labai priklauso nuo biologinio subrendimo laipsnio (Malina, Bouchard, 1991; Quan et al., 2000). Testosterono kiekis kraujo plazmoje koreliuoja su raumenų maksimaliaja jèga (Kraemer \& Feck, 1993). Pubertatiniu laikotarpiu daugejja testosterono (Malina, Bouchard, 1991), ir tai skatina raumenų jègos augimą bei lavèjimą. Atliekant tyrimą nebuvo matuojamas testosterono kiekis kraujyje, tačiau tiriamuju biologinis amžius buvo panašus. Todèl galima teigti, 
kad šis veiksnys nėra svarbiausias vertinant vaiku šoklumo rodiklių skirtumus. Visgi su augimu ir lytiniu brendimu susiję motorikos ypatumai gali labai pakeisti tiriamujų šoklumą.

Svarbiu veiksniu, gerinančiu vaiku šoklumą, reikètų laikyti šoklumą ugdančius krūvius (Kamandulis, Skurvydas, 2003). Nustatyta, kad net per kelias šoklumo treniruotes padideja valinga raumenų susitraukimo jẻga, nes išmokstama geriau atlikti judesi (Schmidt, 1988). Kaip matyti iš tyrimo rezultatu, visų tiriamujų vertikalaus šuolio rodikliai buvo reikšmingai pagerinti. Tai patvirtina mokslininku (Balsom et al., 1992; Glenmark et al., 1992; Komi, 1992) nustatyti organizmo adaptacijos prie fizinių krūvių dèsningumai. Visgi skirtumas tarp silpniausiai ir geriausiai šokančiujų dèl treniruočių poveikio dar labiau išaugo. Ko gero, čia turejjo ittakos daugybè veiksnių, lemiančių skirtingą jaunesniojo mokyklinio amžiaus vaiku reakciją i atliktą fizinị krūvị.

Lemiamos reikšmès čia gali turèti ir tai, kaip moksleivis geba reikiamai susikaupti, ar turi motyvaciją. Dèl šių veiksnių didejja motoneuronų impulsavimo dažnis, vyksta jų mobilizaciją skatinantys procesai, didejja motoneuronų aktyvumo sinchronizacija (Schmidt, 1988). Nuo motorinès programos sudarymo tikslumo priklauso agonistų, sinergetu, antagonistu, rankų ir kojų raumenu koordinacija, kuri padeda geriau atlikti šuoli (Schmidt, 1988; Skurvydas ir kt., 1988). Daug lemia raumenų kompozicija — tiriamujų šoklumas priklauso nuo raumenų susitraukimo ilgio, greitųjų raumeninių skaidulų hipertrofijos (Goldspink, 1992; Enoka, 1994; Häkkinen, 1994), raumenų ir sausgyslių elastingumo (Bosco et al., 1983), taip pat raumeninių sausgyslių prisitvirtinimo kampo (Enoka, 1994).
Tyrimo pradžioje berniukų ir mergaičių šoklumas buvo beveik vienodas, t. y. skyrèsi nereikšmingai. Vèliau išryškèjo, kad berniukų vertikalaus šuolio rezultatai geresni, ir ipusèjus tyrimui jie jau skyrèsi patikimai. Tai patvirtina R. M. Malina ir C. Bouchard (1991) teigini, kad šio amžiaus mergaičių raumenų jèga siekia $75-90 \%$, to paties amžiaus berniuku jègos.

Tyrimo rezultatai parode, kad aštuonių savaičių trukmès vertikalaus šuolio krūviai reikšmingai pagerina šoklumą. Tik būtina žinoti, kad kiekvienu amžiaus tarpsniu šoklumą lemia skirtingi veiksniai, ir tai gali klaidinti trenerius, prognozuojant vaiku ir paauglių raumenu staigiosios jègos galimybes. Biologiškai prasčiau subrendęs vaikas, nors jo organizme ir vyrauja greitosios RS, dažnai dèl neišugdytos raumenu jègos treneriams atrodo neperspektyvus. Šoklumo realizavimo komponentai organizmui vystantis subręsta netolygiai (Skurvydas ir kt., 1988). Iš tyrimo pradžioje nustatytų vertikalių šuolių rodiklių negalime prognozuoti ateities rezultatų.

\section{IŠVADOS}

1. Berniukų ir mergaičių šoklumo rodikliai dèl nuoseklių treniruočių reikšmingai padidejjo, tačiau berniukų šoklumo rezultatų prieaugis buvo reikšmingai didesnis nei mergaičių.

2. Berniukų ir mergaičių vertikalių šuolių rezultatų vidurkio sklaida dèl treniruočių padidèjo, ypač berniuku.

3. Koreliacinè duomenų analizè rodo, kad nei iš mergaičių, nei iš berniukų pirmos treniruotès (ypač silpnas koreliacinis ryšys) šuolių rodiklių negalime prognozuoti galutinių rezultatų.

\section{LITERATŪRA}

Balsom, P. D., Seger, J. Y., Sjodin, B. \& Ekblom, B. (1992). Physiological responses to maximal intensity intermittent exercise. European Journal of Applied Physiology, 65, 144-149.

Booth, F. W. \& Thomason, D. B. (1991). Molecular and cellular adaptation of muscle in response to exercise: Perspectives of various models. Physiology Review, 71 (2), 541-585.

Bosco, C., Komi, P. (1979). Mechanical characteristics and fiber composition of human leg extensors muscles. European Journal of Applied Physiology, 41, 275-284.

Bosco, C., Luhtanen, P., Komi, P. V. (1983). A simple method for measurement of mechanical power in jumping. European Journal of Applied Physiology, 50, 273-282.

Enoka, R. M. (1994) ). Neuromechanical basis of kinesiology. Champaign, IL: Human Kinetics.

Enoka, R. M., Stuart, D. G. (1992). Neurobiology of muscle fatigue. Journal of Applied Physiology, 72, 1631-1648.

Glenmark, B., Hedberg, G., Jansson, E. (1992). Changes in muscle fiber type from adolescence to adulthood in women and men. Acta Physiologica Scandinavica, 146, 251-259.

Goldspink, G. (1992). Cellular and Molecular Aspects of 
Adaptation in Skeletal Muscle. Oxford. P. 211-230.

Häkkinen, K. (1994). Neuromuscular adaptation during strength training, aging, detraining and immobilization. Critical Review in Physical and Rehabilation Medicine, 6 (3), 161-198.

Jaščaninas, J., Skurvydas, A., Mamkus, G. ir Ratkevičius, A. (1989). Ivairaus kryptingumo treniruočių krūviai, raumens susitraukimo greičio jègos ypatybès, ontogenezè ir sportinès atrankos aspektai. Sveikatos apsauga, 6, 24-29.

Kamandulis, S., Skurvydas, A. (2003). Pakartotinio krūvio efektas atliekant valingus ir nevalingus keturgalvio šlaunies raumens susitraukimus. Sporto mokslas, 4, 27-30.

Karoblis, P. (1999). Sporto treniruotés teorija ir didaktika. Vilnius.

Komi, P. V. (1992). Strength and Power in Sport. Oxford.

Kraemer, W. J. \& Fleck, S. J. (1993). Strength Training for Young Athletes. Champaign, IL: Human Kinetics.

Malina, R. M., Bouchard, C. (1991). Growth, Maturation and Physical Activity. Champaigin, IL: Human Kinetics.

Mamkus, G. (1998). Amžiaus ir treniruotès poveikis koju raumenu susitraukimo ir atsipalaidavimo savybèms: disertacijos santrauka. Kaunas.
Quan, D. Q., Xu, C. G., Yian, B. T., Huang, T. T. (2000). The research on development-law of motor coordination ability of children in 7-12 years. International PreOlympic Congress on Sport Science, Sport Medicine and Physical Education, 7-12 September. Brisbene, Australia.

Salmons, S. (1994). Exercise, stimulation and type transformation of skeletal muscle. International Journal of Sports Medicine, 15 (5), 136-141.

Schmidt, R. A. (1988). Motor Control and Motor Learning. Champaign, IL: Human Kinetics.

Skurvydas, A., Stasiulis, A. ir Vilčinskas, P. (1988). Šoklumo fiziologiniai pagrindai. Vilnius.

Spirduso, W. W. (1995). Physical Dimensions of Ageing. Human Kinetics.

Stanislovaitis, A. (1998). Influence of specialized strength, sprint and endurance training loads on adaptation characteristics of the function of human skeletal muscles: summary of doctoral dissertation. Kaunas.

Wilmore, J. H. \& Costill, D. L. (1994). Physiology of Exercise and Sport. Champaign, IL: Human Kinetics.

Zachovajevas, P. (1998). Raumenu mažu dažniu nuovargis atliekant fizinius pratimus maksimaliu intensyvumu: daktaro disertacija. Kaunas: LKKI.

\title{
SPRING CHANGES OF GIRLS AND BOYS
}

\author{
Eduardas Rudas, Albertas Skurvydas, Dalia Mickevičienė, Daiva Bulotienė \\ Lithuanian Academy of Physical Education, Kaunas, Lithuania
}

\begin{abstract}
The study is about spring dynamics of junior school-age boys. 10 year-old children's spring was trained during two months. 16 boys and 17 girls learning in the fourth form took part in the research. The aim of the research was to test the spring dynamics of junior school-age children by training their spring for 2 months. Spring was trained for 2 months twice a week. During the exercises after the 10 minute-warming-up of low intensity pupils used to make 50 springs every 30 seconds. It was recommended to spring as high, as possible. To measure the level of the spring the contact platform was used. It was connected with the electronic meter of the spring that measured the spring's height and the take-off of the time. The results of the pupils' springs were recorded into the individual springs' protocol. Using the methods of statistical mathematics the results of the research were analysed. After the 2-month testing of the junior-age pupils' springs it was found out that: children's springs (both boys and girls, those who exercise actively and who don't) were influenced by training and considerably improved comparing with the first training, and boys' results, after training, were more different than those of girls; both boys and girls results improved gradually; boys improved their average results more than girls; after the exercises the dispersal of pupils' springs increased; as it was showed by the test, it is impossible to foresee the final results of the springs after the first average results of the vertical spring.
\end{abstract}

Keywords: jumping of boys and girls, muscle fatigue, development of power.

Gauta 2005 m. birželio 23 d.

Received on June 23, 2005

Priimta 2005 m. lapkričio 16 d.

Accepted on November 16, 2005
Eduardas Rudas

Lietuvos kūno kultūros akademija

(Lithuanian Academy of Physical Education)

Sporto g. 6, LT-44221 Kaunas

Lietuva (Lithuania)

Tel +370 52701431

E-mail e.rudas@lkka.lt 